\title{
Detection and Significance of Cytotoxic Cell Subsets in Biopsies of HCV-Infected Human Livers
}

\author{
Iwona Mozer-Lisewska $\cdot$ Anna Mania $\cdot$ \\ Arleta Kowala-Piaskowska • Andrzej Kluk • \\ Husam Samara · Anna Pauli · Jan Żeromski
}

Received: 14 January 2013/Accepted: 25 October 2013/Published online: 14 November 2013

(C) The Author(s) 2013. This article is published with open access at Springerlink.com

\begin{abstract}
Chronic viral hepatitis C still remains the clinical challenge. Attempts of the immune system to cope with this infection are unsatisfactory. There is a conviction that the main site of interaction between virus (Hepatitis $\mathrm{C}$ virus, $\mathrm{HCV}$ ) and immune system is in situ, i.e., in liver. Natural killer (NK) cells appeared relevant in the acute hepatitis. Less is known about the immune response in the chronic $\mathrm{HCV}$ infection. The aim of this study was to evaluate the prevalence of various cytotoxic cell subsets in chronic $\mathrm{HCV}^{+}$liver tissue and to seek links between them and laboratory data of patients. Sections from paraffin blocks of liver biopsy tissues of $\mathrm{HCV}^{+}$untreated patients were subjected to the reaction with antibodies vs. cytotoxic cell subsets and immunohistochemistry. Positive cells were searched in cellular infiltrates in portal areas and in liver parenchyma. They were classified on the "Yes" or "No" basis. Majority of liver biopsies exhibited cellular infiltrates in portal spaces and as single cells in liver parenchyma. Infiltrates consisted of $\mathrm{CD}^{+} \mathrm{T}$ cells, $\mathrm{CD} 56^{+} \mathrm{NK}$ ones,
\end{abstract}

I. Mozer-Lisewska · A. Kowala-Piaskowska · A. Pauli Chair and Department of Infectious Diseases, Karol Marcinkowski University of Medical Sciences, Poznan, Poland

\section{A. Mania}

Department of Pediatric Infectious Diseases and Child

Neurology, Karol Marcinkowski University of Medical

Sciences, Poznan, Poland

A. Kluk

Department of Clinical Pathomorphology, Karol Marcinkowski University of Medical Sciences, Poznan, Poland

H. Samara · J. Żeromski ( $\square)$

Department of Clinical Immunology, Karol Marcinkowski

University of Medical Sciences, Poznan, Poland

e-mail: jzeromski@ump.edu.pl including $\mathrm{CD} 158 \mathrm{i}^{+}$and $\mathrm{CD} 158 \mathrm{~b}^{+}$. The latter were rarely seen. There were also granzyme $\mathrm{B}^{+}$cells. The most abundant were $\mathrm{NKG}_{2} \mathrm{D}^{+}$cells, much more common than NK $\mathrm{CD}^{+} 6^{+}$ones. It implied that NKG2D was also expressed on $\mathrm{T}$ cells. Prevalence of $\mathrm{NKG}_{2} \mathrm{D}^{+}$cells correlated with high activity of liver enzymes such as alanine aminotransferase, aspartate aminotransferase and a greater histological severity of liver injury. $\mathrm{NKG}_{2} \mathrm{D}^{+}$cells form the bulk of cells infiltrating $\mathrm{HCV}$-infected human liver. Correlation of $\mathrm{NKG}_{2} \mathrm{D}^{+}$cells with some laboratory parameters of patients suggests their role in hepatitis $\mathrm{C}$ pathogenesis.

Keywords $\mathrm{HCV}^{+}$liver biopsy $\cdot \mathrm{NK}$ cells .

Cytotoxic T cells $\cdot$ NKG2D receptor .

Immunohistochemistry $\cdot$ Patients data

$\begin{array}{ll}\text { Abbreviations } \\ \text { ALT } & \text { Alanine aminotransferase } \\ \text { AST } & \text { Aspartate aminotransferase } \\ \text { CD } & \text { Cluster determinant } \\ \text { HCV } & \text { Hepatitis C virus } \\ \text { IHC } & \text { Immunohistochemistry } \\ \text { NK } & \text { Natural killer } \\ \text { NKT } & \text { Natural killer T cells }\end{array}$

\section{Introduction}

Chronic viral hepatitis $\mathrm{C}$ remains one of the most challenging human diseases. It affects almost 200 million people worldwide. Inflammatory processes lead to severe liver damage manifested by fatty change, cell infiltrates, hepatocyte apoptosis, culminating in liver cirrhosis and finally hepatocellular carcinoma. As specific vaccine is still 
unavailable, hepatitis $\mathrm{C}$ virus (HCV) infection spreads out by various parenteral routes worldwide, particularly in developing countries (Rantala and van de Laar 2008; Thomas and Seeff 2005).

The host immune system has only limited tools to control $\mathrm{HCV}$ entry into the body. Infected cells secrete interferon type I $(\alpha)$ that has a virostatic effect and partly prevents infection of surrounding cells. Natural killer (NK) cells are the only ones of innate immunity, able to kill cells already infected by the virus in question. They possess the ability to discern self from non-self, either by the recognition of viral peptides on the cell surface, or by down-regulation or loss of some MHC molecules (Lodoen and Lanier 2006). The latter happens mainly in cancer, but also in viral invasions and affects various HLA A-C alleles. This peculiar feature of NK cells is due to the expression on their surface of several sets of receptors such as immunoglobulin-like ones (KIR), lectin-like ones, natural cytotoxic ones and others. Receptor ligands are various HLA alleles, both polymorphic and nonpolymorphic but also some viral antigens, for example, influenza hemagglutinin. Receptors are either inhibitory or activating, depending on the recognized ligand (Bryceson et al. 2011). It has been reported that the reduction of expression of some NK receptors in recently $\mathrm{HCV}$-infected patients may be linked to virus clearance (Alter et al. 2011). Induction of apoptosis of HCV-infected hepatocytes by $\mathrm{NK}$ cells has been shown in acute phase of hepatitis $\mathrm{C}$, manifested occasionally by the inhibition of viral spread (Golden-Mason et al. 2010; Zou et al. 2010). Relatively little, however, is known about the function and biological significance of NK cells in chronic phase of this disease, in spite of considerable body of research on this disease (Brenndorfer and Sallberg 2012; Zeromski et al. 2011). Several authors have investigated other lymphoid cell subsets of liver infiltrates, such as T cells, B cells, etc. (Fiore et al. 1997; Koziel and Walker 1997). T-regulatory cells were extensively studied by various groups and considered to be involved in the induction of tolerance to viral antigens in affected hosts (Amoroso et al. 2012; Miyaaki et al. 2009). On the contrary, NK cells were found to be suppressed by HCV proteins (Cheent and Khakoo 2011; Varchetta et al. 2012; Wen et al. 2008). Their frequencies in peripheral blood are reduced in chronic HCV infections (Cheent and Khakoo 2011). It has been postulated that direct cell-to-cell contact of NK cells with infected hepatocytes inhibits cytotoxicity of these cells (Yoon et al. 2011). Recently however, it has been shown in animal studies that mice (depleted of NK cells) infected with lymphocytic choriomeningitis virus (LCMV) are able to mount efficient adaptive $\mathrm{CD}^{+}{ }^{+} \mathrm{T}$-cell response against LCMV (Lang et al. 2012). Thus, a possible regulatory role for NK cells in chronic viral infections has emerged and deserves investigation. Relatively little is known about another cell subset, namely natural killer T (NKT) cells $\left(\mathrm{CD}^{2} 6^{+}, \mathrm{CD}^{+}\right)$, constituting 5-10\% of human liver lymphocytes. They recognize lipid antigens presented by the non-classical MHC class I-like molecules CD1. Most of them possess an invariant T-cell receptor $\alpha$. When activated, NKT cells can produce large quantities of several cytokines such as IFN- $\gamma$, IL-17, TNF- $\alpha$ and others, as well as cytotoxic mediators including Fas ligand and TRAIL. Their activating ligands are unknown, making their functional utility elusive (Gao et al. 2009).

The aim of this study was to search for NK cells, some of their subsets as well as $\mathrm{T}$ cells in situ by immunohistochemistry (IHC) in tissues of diagnostic liver biopsies collected from $\mathrm{HCV}$-infected patients prior to anti-viral therapy and compare these data to various clinical/laboratory parameters of individual patients. It was expected that such information might have some predictive value. It will be shown that some relationships do exist.

\section{Materials and Methods}

\section{Patients}

Patients were routinely admitted to the Hepatology Policlinic of Poznan J. Strus Municipal Hospital with suspected HCV infection. When registered, they signed written informed consent for their thorough diagnostic procedures and anti-viral therapy. They were submitted to comprehensive clinical and laboratory examinations, including the determination of anti-HCV antibodies, quantitative RNAHCV viral load (Amplicor Monitor Test, Version 2.0Roche, detection limit $50 \mathrm{IU} / \mathrm{mL}$ ), alanine aminotransferase (ALT), aspartate aminotransferase (AST), $\gamma$ glutamyltransferase liver enzymes activity, bilirubin content, $\alpha$-fetoprotein and percutaneous liver biopsy. All procedures were in agreement with ethical guidelines of the 1975 Declaration of Helsinki and were approved by the Medical School Bioethics Committee.

\section{Patient's Tissues}

Paraffin blocks with embedded liver biopsy fragments from $56 \mathrm{HCV}^{+}$patients were used. Liver biopsy was routinely performed before anti-viral therapy. Hematoxylin and eosin $(\mathrm{H}+\mathrm{E})$ stained $4 \mu \mathrm{m}$ sections, cut from paraffin liver tissue blocks, were evaluated for grading and staging utilizing METAVIR (1994) scale.

Immunohistochemistry

Formalin fixed, paraffin wax embedded liver specimens were cut in $4 \mu \mathrm{m}$ sections. The latter were mounted on 
Table 1 Primary antibodies used

\begin{tabular}{llllll}
\hline Specificity & Animal & Type & Clone & Source & Catalog number \\
\hline CD56/NCAM & Mouse & Monoclonal & CD564 & Leica Microsystems & NCL-CD56-504 \\
CD3 & Rabbit & Polyclonal & NS & Dako & IR503 \\
CD8 & Mouse & Monoclonal & 1A5 & Leica & NCL-CD8-295 \\
NKG2D/CD314 & Rabbit & Polyclonal & KLRK1 & Bioss Inc. & bs-0938R \\
NKG2D/CD314 & Mouse & Monoclonal & 1D11 & Novus Biologicals & NB100-65956 \\
Granzyme B & Mouse & Monoclonal & GZB01 & Abcam & Ab3654 \\
KIR2DS4/CD158i & Rabbit & Polyclonal & NS & Bioss Inc. & Bs-2644R \\
KIR2DL2/CD158b & Rabbit & Polyclonal & NS & Bioss Inc. & Bs-2642R \\
\hline
\end{tabular}

NS not shown

adhesive microscopic slides (Super FrostPlus, Menzel Glaser), dewaxed with xylene, and dehydrated in decreasing content of alcohol. Antigen retrieval was obtained by heating in a water bath (buffer-Epitope Retrieval Solution, $\mathrm{pH}$ 9, Novocastra Leica Microsystems) for $50 \mathrm{~min}$ at $98{ }^{\circ} \mathrm{C}$. Endogenous peroxidase was blocked by $3 \%$ hydrogen peroxide for $20 \mathrm{~min}$ and thereafter sections were then incubated with primary antibody in a humidified chamber at $4{ }^{\circ} \mathrm{C}$ overnight. The primary antibodies and their concentrations used are depicted in Table 1. Primary antibodies were diluted using IHC Diluent (Leica Microsystems). For each section, a negative control was performed. Instead of primary antibody, IHC Diluent was applied. As positive controls, the following tissue sections were used: for granzyme B-Hodgkin's lymphoma, for CD56-large bowel, for NKG2D_CD158i and CD158b hyperplastic lymph node. The immunoreaction was localized using the NovoLink Polymer Detection System (Leica Microsystems). It is a two-step streptavidin-biotin-peroxidase method. Each slide was incubated for $30 \mathrm{~min}$ at room temperature. Between reaction steps, slides were washed thrice in Tris-buffered saline ( $\mathrm{pH} \mathrm{7.6)} \mathrm{for} 5 \mathrm{~min}$. Visualization of reaction was achieved by 3,3'-diaminobenzidine tetrachloride (DAB) (Leica Microsystems). Sections were counterstained with Mayer's hematoxylin, dehydrated, cleared and mounted in Canada balsam.

\section{Evaluation of IHC Reactions}

Slides were evaluated by competent, experienced immunopathologist (JZ) using a research light microscope (Olympus BX40), with $40 \times$ objective (magnification $400 \times$ ), and five high-power fields were searched for:

- the presence of positive cells in portal areas and/or in liver parenchyma, and

- positive cells in cell clusters and/or single dispersed ones.
Statistical Analysis

It was performed using Statistica StatSoft package. Analyzed data was not normally distributed. The parametric data comparisons were made by Mann-Whitney $U$ test. Nonparametric data were compared using Fisher's test, the Chi-square test and Spearman rank correlation test. Continuous variables were tested for normality using ShapiroWilk test and compared using Mann-Whitney $U$ test. Categorical variables were tested using Fisher's exact test or Chi-square test, where appropriate. Correlations were performed using Spearman rank correlation test. Univariate analysis was performed on chosen parameters. Significant parameters were included in multivariate analysis. Values were considered statistically significant if $p<0.05$ or confidence interval did not include 1 .

\section{Results}

Frequency of detection of positive cells either in singles or in clusters is shown in Table 2. It can be seen that $\mathrm{NKG}_{2} \mathrm{D}^{+}$cells were most frequently observed, predominantly in portal areas. It was also true for the remaining NK cells such as $\mathrm{CD}^{+} 6^{+}, \mathrm{CD}_{158 \mathrm{i}^{+}}$and $\mathrm{CD} 158 \mathrm{~b}^{+}$ones.

Table 2 Prevalence of positive cells in IHC reactions

\begin{tabular}{llll}
\hline $\begin{array}{l}\text { Antibody } \\
\text { vs. }\end{array}$ & $\begin{array}{l}\text { Single positive } \\
\text { cells }\end{array}$ & $\begin{array}{l}\text { Positive cell } \\
\text { clusters }\end{array}$ & $\begin{array}{l}\text { Lack of } \\
\text { positive cells }\end{array}$ \\
\hline CD56 & 32 & 16 & 8 \\
Granzyme & 24 & 11 & 21 \\
$\quad$ B & & & \\
NKG2D & 7 & 36 & 13 \\
CD158i & 20 & 22 & 14 \\
CD158b & 9 & 4 & 43
\end{tabular}

Total biopsies tested: 56 
Granzyme $\mathrm{B}^{+}$cells were also mainly seen within portal spaces. $\mathrm{NK}^{+}$cells were only rarely seen as single ones dispersed in liver parenchyma. On the contrary, $\mathrm{T}$ cells (both $\mathrm{CD}^{+}$and $\mathrm{CD}^{+}$) apart from portal spaces were frequently seen between hepatocytes (Figs. 1, 2).

There was no correlation among CD56-positive cells and the results of histopathology, viral load and biochemical assays. The observed differences were not statistically significant. The expression of NK cell receptors, CD158i and $158 \mathrm{~b}$ also did not correlate significantly with deviations in biochemistry (Tables 3,4 ).

In order to investigate the correlation between the most frequently seen $\mathrm{NKG}_{2} \mathrm{D}^{+}$cells in $\mathrm{HCV}^{+}$liver and clinical parameters of patients, NKG2D cell expression was compared to the patients laboratory data (Tables 3, 4). It was found that NKG2D expression on cells infiltrating $\mathrm{HCV}^{+}$ liver showed a correlation with the rise of activity of liver enzymes, ALT and AST (Figs. 3, 4, 5, 6). There was also a correlation between the histological grading and the intensity of liver steatosis and the prevalence of NKG2D ${ }^{+}$ cells (Fig. 7).

\section{Discussion}

The results of the present study indicate that cellular infiltrates in $\mathrm{HCV}^{+}$human liver are quite complex and consist of several cell types in various proportions. We were initially mainly interested in screening NK cells and their markers related to their cytotoxic properties in virally infected liver. It turned out that other cell subsets have to be taken into account while looking for cells able to eliminate infected hepatocytes. Such cells were most abundant in portal areas, forming dense cellular infiltrates. They, however, could be also seen as single dispersed ones, in liver parenchyma between hepatocytes. In general, NK
Fig. 1 Immunohistochemical pictures of NK cells in HCVinfected liver tissues (1-6). a Single positive cells in cellular infiltrate of portal area, antiCD56 monoclonal antibody (MoAb), ABC

immunohistochemistry (IHC) reaction. b Single positive cells in liver parenchyma (arrows), anti-CD56 MoAb, the reaction as previously. c Abundant positive cells in cellular infiltrate of portal area, antiNKG2D MoAb, ABC IHC. d Single positive cells in liver parenchyma (arrows), the reaction as previously. e Single positive dispersed cells in liver cellular infiltrate (arrows), antiCD158i NK antibody (Ab), ABC IHC. f Single positive cells in liver cellular infiltrate (arrows), anti-CD158b NK Ab, ABC IHC. Bar in all $50 \mu \mathrm{m}$
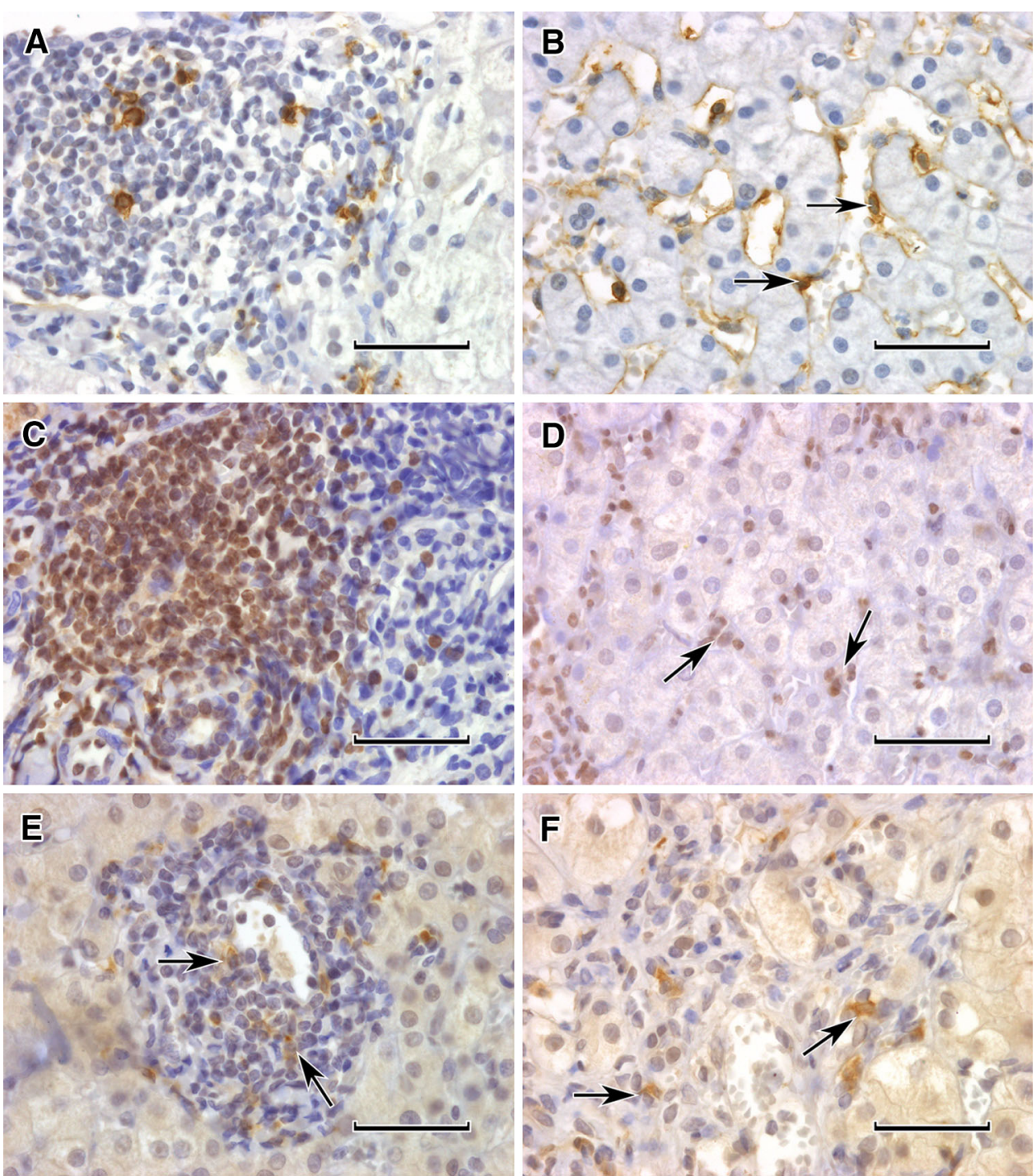
Fig. 2 Immunohistochemical pictures of T-cell subsets and granzyme B in HCV-infected liver tissues (1-8). a Visible abundant cellular infiltrate in portal area, control reaction, PBS instead of primary antibody followed by ABC IHC, $\mathrm{H}+\mathrm{E}$ counterstain. b Positive cells visible both in cellular infiltrate of portal area and in liver parenchyma, anti-T CD3 $\mathrm{Ab}, \mathrm{ABC}$ IHC. c As previously but only portal area. d As previously but liver parenchyma, visible single positive cells. e Abundant dense cellular infiltrate, numerous positive cells visible, anti-T CD8 MoAb, ABC IHC. f As previously but liver parenchyma, visible single dispersed positive cells. g Intensive cellular infiltrate in portal area, single dispersed positive cells visible (arrows), anti-granzyme B MoAb. h As previously but high power (arrows). Bar in all $50 \mu \mathrm{m}$
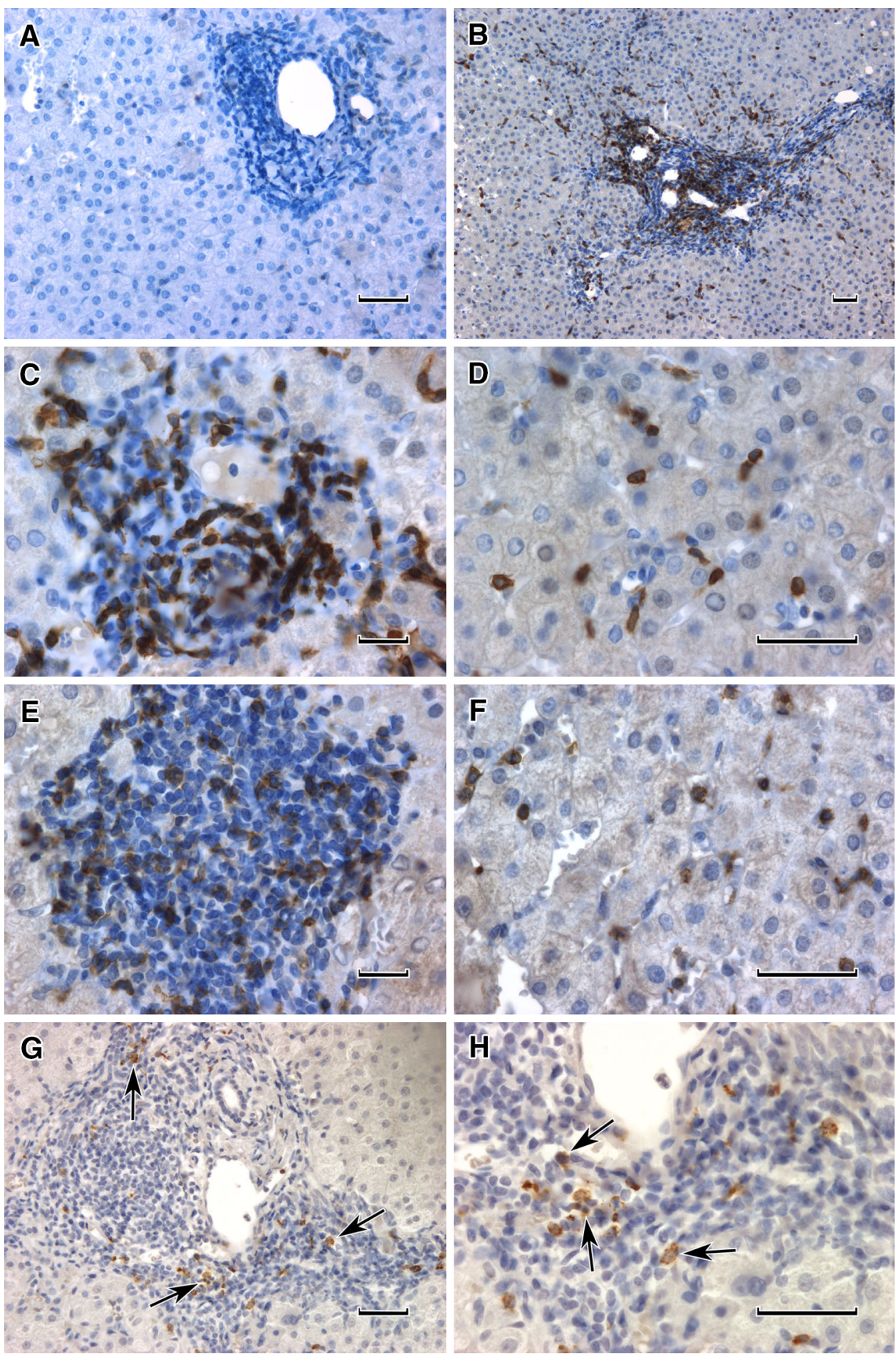

cells represented by $\mathrm{CD}_{5} 6^{+}$or $\mathrm{CD} 158 \mathrm{i}^{+}$were predominantly seen in cellular infiltrates, while only rarely spotted between liver cells. On the contrary, T cells, $\mathrm{CD}^{+}$or $\mathrm{CD}^{+}$ones, apart from strong representation in cell infiltrates, were quite common in liver parenchyma. This finding is unexplained, but suggests that effector cells of adaptive immunity such as $\mathrm{CD} 8^{+} \mathrm{T}$ cells are presumably more efficient in eliminating the infected hepatocytes than NK cells in the chronic phase of HCV infection (Lauer et al. 2002). It has been found that intrahepatic $\mathrm{CD} 8^{+} \mathrm{T}$ cells show higher NKG2D expression than circulating $\mathrm{CD}^{+}{ }^{+} \mathrm{T}$ ones (Kennedy et al. 2008). All patients in the present study were yet to undergo anti-viral therapy, meaning that the observed findings are exclusively the 
Table 3 Biochemical parameters, viral load, histology of biopsy tissue in a studied group depending on NKG2D expression on cellular infiltrates

\begin{tabular}{|c|c|c|c|}
\hline Parameter & $\begin{array}{l}\text { Patient's subgroup } \\
\text { with NKG2D } \\
\text { expression }(n=43)\end{array}$ & $\begin{array}{l}\text { Patient's subgroup } \\
\text { without NKG2D } \\
\text { expression }(n=13)\end{array}$ & $p$ \\
\hline Viremia $\log 10$ & $4.40 \pm 0.95$ & $4.58 \pm 0.99$ & 0.565 \\
\hline $\begin{array}{l}\text { ALT }>\text { Y } / \mathrm{N} \\
\text { (normal } \\
\text { limit up to } \\
40 \mathrm{IU} / \mathrm{L})\end{array}$ & $30 / 13$ & $5 / 8$ & $0.044 *$ \\
\hline $\begin{array}{r}\text { ALT before } \\
\text { treatment }\end{array}$ & $67.03 \pm 41.22$ & $39.39 \pm 24.47$ & $0.012 *$ \\
\hline $\begin{array}{l}\text { AST }>\text { Y/N } \\
\text { (normal } \\
\text { limit up to } \\
42 \text { IU/L) }\end{array}$ & $18 / 25$ & $3 / 10$ & 0.856 \\
\hline $\begin{array}{r}\text { AST before } \\
\text { treatment }\end{array}$ & $42.00 \pm 21.77$ & $28.96 \pm 11.59$ & $0.014 *$ \\
\hline AFP & $7.29 \pm 13.25$ & $6.28 \pm 11.27$ & 0.199 \\
\hline $\begin{array}{l}\text { GGTP (normal } \\
\text { limit up to } \\
60 \mathrm{U} / \mathrm{L} \text { ) }\end{array}$ & $43.74 \pm 32.95$ & $37.62 \pm 21.03$ & 0.819 \\
\hline Grading & $1.67 \pm 0.71$ & $1.15 \pm 0.55$ & $0.019 *$ \\
\hline Staging & $1.744 \pm 1.00$ & $1.1 \pm 0.48$ & 0.136 \\
\hline $\begin{array}{l}\text { Prevalence of } \\
\text { steatosis } \\
\mathrm{Y} / \mathrm{N}\end{array}$ & $18 / 25$ & $2 / 11$ & 0.075 \\
\hline $\begin{array}{r}\text { Percent of } \\
\text { steatosis }\end{array}$ & $10.37 \pm 19.75$ & $2.54 \pm 5.67$ & 0.71 \\
\hline Bilirubin level & $0.86 \pm 0.56$ & $0.96 \pm 0.52$ & 0.317 \\
\hline
\end{tabular}

$A F P \alpha$-fetoprotein, GGTP $\gamma$ glutamyltransferase, $Y / N$ yes $/$ no $* p<0.05$

host's immune system attempts to cope with $\mathrm{HCV}$ infection.

An interesting observation was the abundance of $\mathrm{NKG}_{2} \mathrm{D}^{+}$cells in cellular infiltrates predominantly in portal areas. Their density was much stronger than that of $\mathrm{CD}^{+} 6^{+}$cells, implying that other cells presumably $\mathrm{T}$ cells express NKG2D, apart from NK ones. The expression of NKG2A inhibitory receptor by activated $\mathrm{T}$ cells in chronic hepatitis C was shown by Nattermann et al. (2006). NKG2D (CD314) is an activating receptor but belongs to the same C-type lectin family of NK receptors as NKG2A. It is expressed on $\mathrm{NK}$ cell subset and memory $\mathrm{T}$ cells (Ahlenstiel and Rehermann 2007). Its ligands are stressinducible MICA and MICB, MHC class I-like proteins, usually expressed in low quantities on epithelial cells (in particular, of gastrointestinal tract) but upregulated on infected ones, sufficient to activate NK cell receptors such as NKG2D (Delves et al. 2011). This may be the case in chronic hepatitis $\mathrm{C}$. At any rate, $\mathrm{NKG}_{2} \mathrm{D}^{+}$cells were the most frequently seen NK cell receptors tested in the present study. The specificity of IHC reaction was confirmed by the
Table 4 Relationship between in situ cell NKG2D expression and patient's laboratory parameters

\begin{tabular}{|c|c|c|c|c|}
\hline \multirow[t]{2}{*}{ Factor } & \multicolumn{2}{|c|}{ Univariate analysis } & \multicolumn{2}{|c|}{ Multivariate analysis } \\
\hline & OR $(95 \% \mathrm{CI})$ & $p$ & OR $(95 \% \mathrm{CI})$ & $p$ \\
\hline $\begin{array}{l}\text { Log } 10 \mathrm{HCV}- \\
\text { RNA }\end{array}$ & $1.22(0.60-2.50)$ & 0.558 & - & \\
\hline $\mathrm{ALT}>\mathrm{UNL} \mathrm{Y} / \mathrm{N}$ & $0.27(0.07-1.01)$ & $0.047 *$ & - & \\
\hline $\begin{array}{l}\text { ALT IU/L before } \\
\text { treatment }\end{array}$ & $0.97(0.94-0.99)$ & $0.027 *$ & $0.98(0.93-1.02)$ & 0.3 \\
\hline $\mathrm{AST}>\mathrm{UNL} \mathrm{Y} / \mathrm{N}$ & $0.42(0.09-1.79)$ & 0.228 & - & \\
\hline $\begin{array}{l}\text { AST IU/L before } \\
\text { treatment }\end{array}$ & $0.94(0.88-0.99)$ & $0.038 *$ & $0.98(0.89-1.09)$ & 0.8 \\
\hline $\begin{array}{l}\text { Bilirubin } \mathrm{mg} / \mathrm{dL} \\
\text { before } \\
\text { treatment }\end{array}$ & $1.38(0.45-4.15)$ & 0.570 & - & \\
\hline $\begin{array}{r}\text { AFP before } \\
\text { treatment }\end{array}$ & $0.99(0.93-1.05)$ & 0.801 & - & \\
\hline GGTP IU/L & $0.99(0.97-1.02)$ & 0.543 & $0.46(0.12-1.69)$ & 0.23 \\
\hline Grading & $0.29(0.09-0.89)$ & $0.028 *$ & - & \\
\hline Staging & $0.55(0.24-1.24)$ & 0.141 & - & \\
\hline Steatosis $\mathrm{Y} / \mathrm{N}$ & $0.25(0.05-1.33)$ & 0.097 & - & \\
\hline
\end{tabular}

$A F P$ a-fetoprotein, GGTP $\gamma$ glutamyltransferase, $U N L$ upper normal limit, $O R$ odd ratio, $C I$ confidence interval, $Y / N$ yes/no

$* p<0.05$

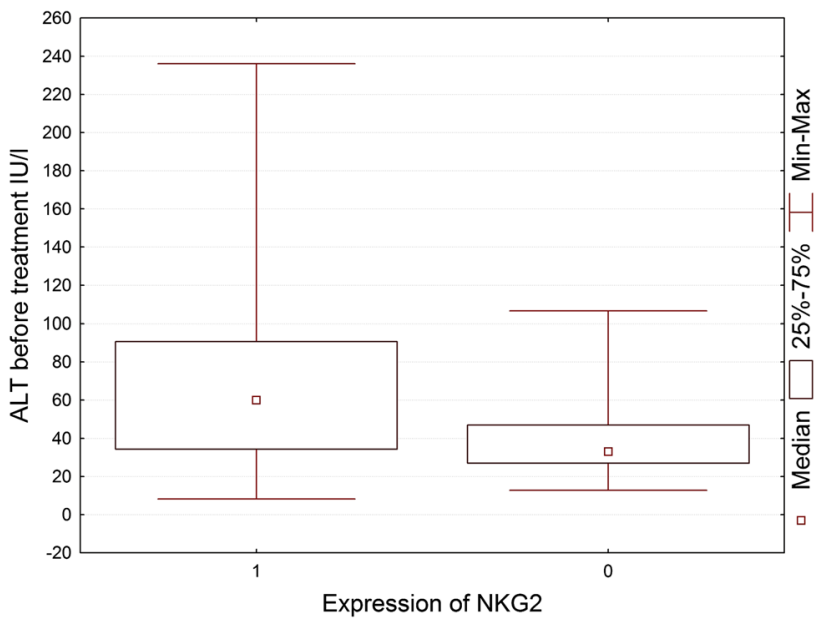

Fig. 3 Median ALT activity before anti-viral treatment in children with and without expression of NKG2 in the liver biopsy specimens

use of two distinct (monoclonal and polyclonal) antibodies of anti-NKG2D receptor. Thus, it seemed of interest to compare their expression with clinical parameters of patients. When mean values of individual factors of $\mathrm{HCV}^{+}$ patients were related to mean NKG2D-positive and NKG2D-negative liver biopsies, some relationships were found to be significant. It was evident for both ALT and AST liver enzymes, and histological grading that high values of these parameters correlated with the relative abundance of NKG2D ${ }^{+}$cells in liver tissues. This was also 


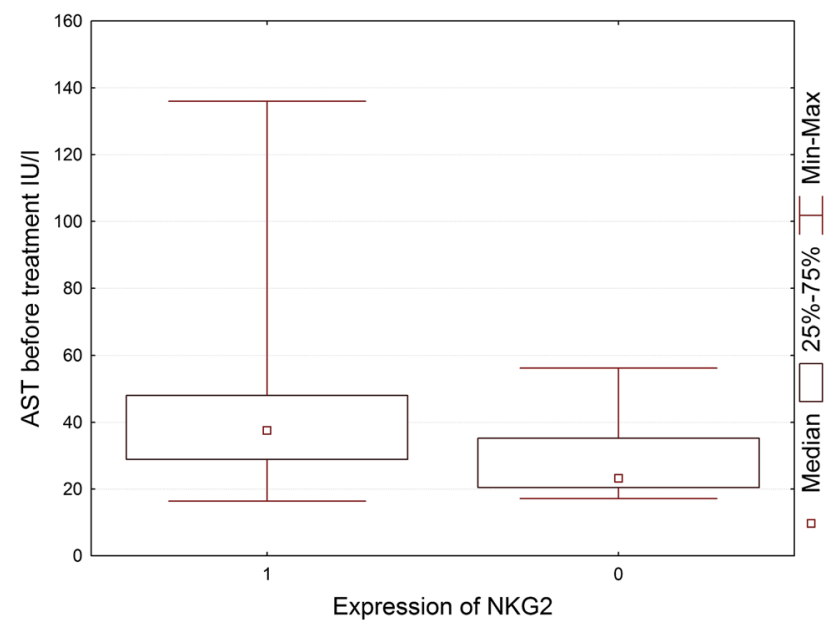

Fig. 4 Median AST activity before anti-viral treatment in children with and without expression of NKG2 in the liver biopsy specimens

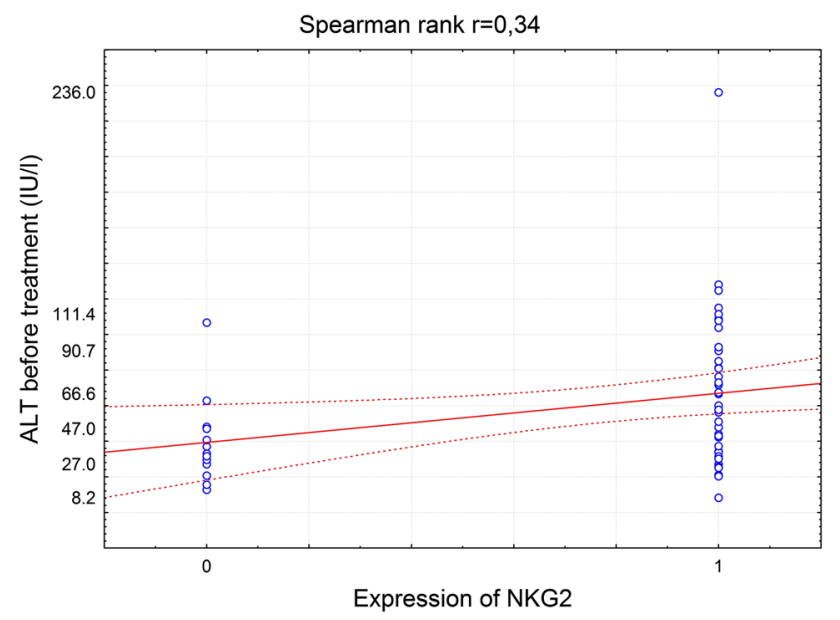

Fig. 5 Spearman rank correlation between ALT activity and NKG2 expression in liver biopsy specimens

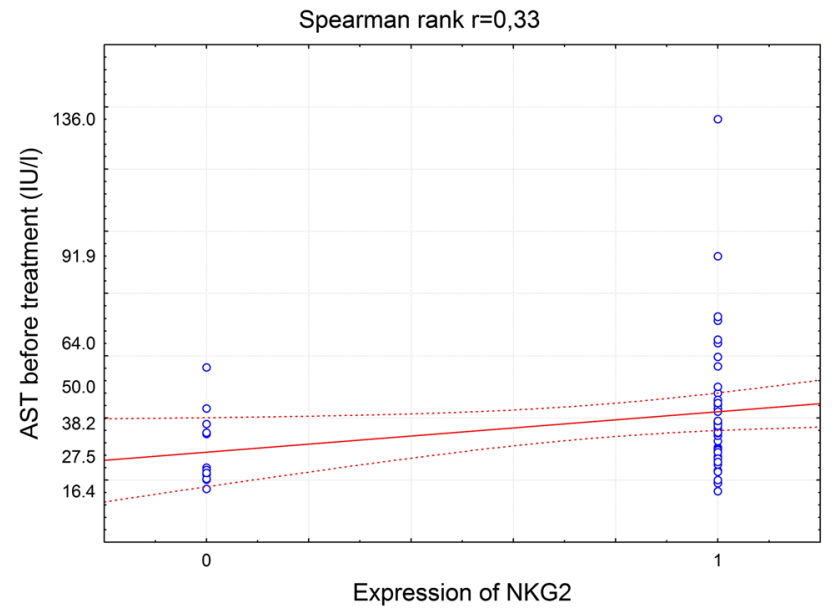

Fig. 6 Spearman rank correlation between AST activity and NKG2 expression in liver biopsy specimens

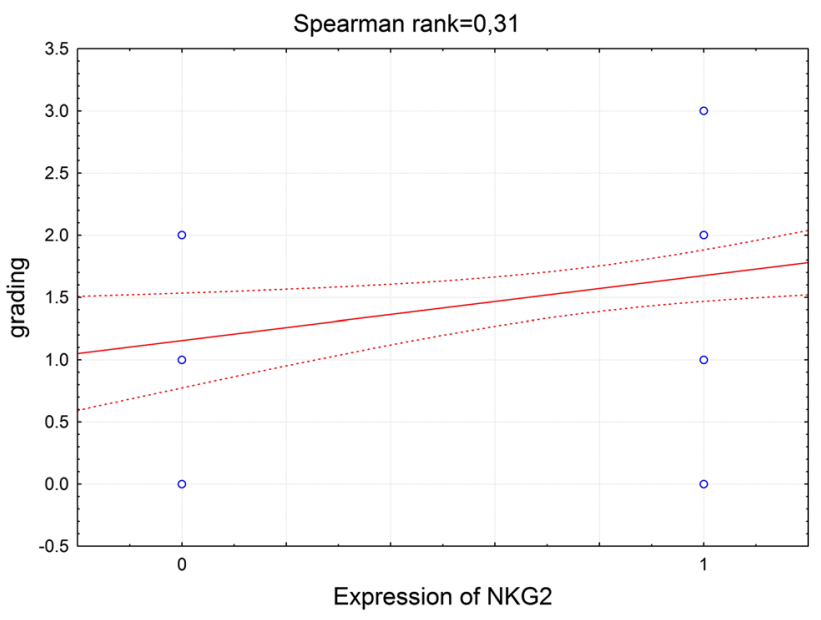

Fig. 7 Spearman rank correlation between scores of histological grading and cell NKG2 receptor expression in liver biopsy specimens

confirmed in univariate but not in multivariate analysis. It suggests that cells expressing NKG2D activating receptor, both NK and $\mathrm{T}$ cells, participate in hepatitis $\mathrm{C}$ pathogenesis, apparently manifesting cytotoxic potential.

Acknowledgments This work was supported by the Project Grant No. NN 401535740 from the Polish National Science Centre (to Prof. I. Mozer-Lisewska).

Conflict of interest All authors of this article declare that they have no competing financial interests related to the presented work.

Open Access This article is distributed under the terms of the Creative Commons Attribution License which permits any use, distribution, and reproduction in any medium, provided the original author(s) and the source are credited.

\section{References}

Ahlenstiel G, Rehermann B (2007) Hepatic NK, NKT and T cells. In: Gershwin ME, Vierling JM, Manns MP (eds) Liver immunology. Principles and practice. Humana Press, Totowa, pp 71-82

Alter G, Jost S, Rihn S et al (2011) Reduced frequencies of NKp30+, NKp46+, CD161+ and NKG2D+ NK cells in acute HCV infection may predict viral clearance. J Hepatol 55:278-288

Amoroso A, D'Amico F, Consolo M et al (2012) Evaluation of circulating CD4+ CD25+ and liver-infiltrating Foxp3+ cells in HCV-associated liver disease. Int J Mol Med 29:983-988

Brenndorfer ED, Sallberg M (2012) Hepatitis C virus-mediated modulation of cellular immunity. Arch Immunol Ther Exp 60:315-329

Bryceson YT, Chiang SC, Darmanin S et al (2011) Molecular mechanisms of natural killer cell activation. J Innate Immun 3:216-226

Cheent K, Khakoo SI (2011) Natural killer cells and hepatitis C: action and reaction. Gut 60:268-278

Delves PJ, Martin SJ, Burton DR et al (2011) Membrane receptors for antigen. In: Delves P et al (eds) Roitt's essential immunology, 12th edn. Wiley-Blackwell, Oxford, pp 79-112 
Fiore G, Angarano G, Cacceta L et al (1997) In-situ immunophenotypic study of hepatic-infiltrating cytotoxic cells in chronic active hepatitis C. Eur J Gastroenterol Hepatol 9:491-496

Gao B, Radaeva S, Park O (2009) Liver natural killer and natural killer $\mathrm{T}$ cells: immunobiology and emerging roles in liver diseases. J Leukoc Biol 86:513-528

Golden-Mason L, Cox AL, Randall JA et al (2010) Increased natural killer cell cytotoxicity and NKp30 expression protects against hepatitis $\mathrm{C}$ virus infection in high-risk individuals and inhibits replication in vitro. Hepatology 52:1581-1589

Kennedy P, Gehring AJ, Nowbath A et al (2008) The expression and function of NKG2D molecule on intrahepatic CD8 ${ }^{+} \mathrm{T}$ cells in chronic viral hepatitis. J Viral Hepat 15:9001-9009

Koziel MJ, Walker BD (1997) Characteristics of the intrahepatic cytotoxic $\mathrm{T}$ lymphocyte response in chronic hepatitis $\mathrm{C}$ virus infection. Springer Semin Immunopathol 19:69-83

Lang PA, Lang KS, Xu HC et al (2012) Natural killer cell activation enhances immune pathology and promotes chronic infection by limiting $\mathrm{CD}^{+} \mathrm{T}$ cell immunity. Proc Natl Acad Sci USA 109:1210-1215

Lauer GM, Ouchi K, Chung RT et al (2002) Comprehensive analysis of CD8 (+)-T-cell responses against hepatitis C virus reveals multiple unpredicted specificities. J Virol 76:6104-6113

Lodoen MB, Lanier LL (2006) Natural killer cells as an initial defense against pathogens. Curr Opin Immunol 18:391-398

Miyaaki H, Zhou H, Ichikawa T et al (2009) Study of liver-targeted regulatory $\mathrm{T}$ cells in hepatitis $\mathrm{B}$ and $\mathrm{C}$ virus in chronically infected patients. Liver Int 29:702-707
Nattermann J, Feldmann G, Ahlenstiel G et al (2006) Surface expression and cytolytic function of natural killer cell receptors is altered in chronic hepatitis C. Gut 55:869-877

Rantala M, van de Laar MJ (2008) Surveillance and epidemiology of hepatitis B and C in Europe-a review. Euro Surveill 13:pii 18880

The French METAVIR Cooperative Study Group (1994) Intraobserver and interobserver variations in liver biopsy interpretation in patients with chronic hepatitis C. Hepatology 20(1 Pt 1):15-20

Thomas DL, Seeff LB (2005) Natural history of hepatitis C. Clin Liver Dis 9:383-398

Varchetta S, Mele D, Mantovani S et al (2012) Impaired intrahepatic natural killer cell cytotoxic function in chronic hepatitis $\mathrm{C}$ virus infection. Hepatology 56:841-849

Wen C, He X, Ma H et al (2008) Hepatitis C virus infection downregulates the ligands of the activating receptor NKG2D. Cell Mol Immunol 5:475-478

Yoon JC, Lim JB, Park JH et al (2011) Cell-to-cell contact with hepatitis $\mathrm{C}$ virus-infected cells reduces functional capacity of natural killer cells. J Virol 85:12557-12569

Zeromski J, Mozer-Lisewska I, Kaczmarek M et al (2011) NK cells prevalence, subsets and function in viral hepatitis C. Arch Immunol Ther Exp 59:449-455

Zou Y, Chen T, Han M et al (2010) Increased killing of liver NK cells by Fas/Fas ligand and NKG2D/NKG2D ligand contributes to hepatocyte necrosis in virus induced liver failure. J Immunol 184:466-475 